\title{
The Ameliorate Effects of Nerolidol on Thioacetamide-induced Oxidative Damage in Heart and Kidney Tissue
}

\author{
Kalp ve Böbrek Dokusunda Tiyoasetamid Kaynaklı Oksidatif Hasarın \\ Üzerine Nerolidolün Koruyucu Etkileri
}

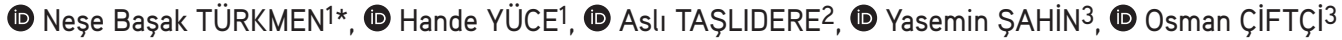 \\ 1|nönü University Faculty of Pharmacy, Department of Pharmaceutical Toxicology, Malatya, Turkey \\ 2'inönü University Faculty of Medicine, Department of Histology and Embryology, Malatya, Turkey \\ 3Pamukkale University Faculty of Medicine, Department of Medicinal Pharmacology, Denizli, Turkey
}

\section{ABSTRACT}

Objectives: Thioacetamide (TAA) is an organosulfur, white crystalline compound having liver injury. However, it shows toxic effects on many organs. The reverts the oxidative stress created by TAA on the heart and kidney, and decreased lipid peroxide peroxidation back with antioxidantproperties nerolidol (NRL). This study hypothesized that NRL treatment a potential ameliorate nephrotoxicity and cardiotoxicity caused by TAA.

Materials and Methods: Thirty-two Wistar Albino male rats (3-4 months old and 280-300 g in weight) were divided into four groups. (a) Control, (b) TAA was administered $200 \mathrm{mg} / \mathrm{kg}$ i.p. twice a weekly (c) NRL was orally administered at the dose of $100 \mathrm{mg} / \mathrm{kg}$ per every other day by gavages. (d) TAA and NRL-treated groups were assigned $200 \mathrm{mg} / \mathrm{kg}$ TAA and $100 \mathrm{mg} / \mathrm{kg}$ NRL for three weeks.

Results: As a result of these dose administration thiobarbituric acid reactive substances (TBARS) levels, superoxide dismutase (SOD), catalase (CAT), glutathione (GSH), and glutathione peroxidase (GPx) levels were detected. The results were shown that TAA leads to a significant rise in TBARS level and a significant decrease in GPx, CAT, SOD, and GSH levels in the heart and kidney tissue according to the control group. The finding of this study the NRL treatment reduced TBARS levels and increased antioxidant level. Administration of NRL prevents the biochemical and histopathological alterations induced by TAA.

Conclusion: The findings of this study show that the antioxidant activity of NRL can protect against biochemical and histological damage caused by TAA in heart and kidney tissue.

Key words: Nerolidol, thioacetamide, lipid peroxidation, nephrotoxicity, cardiotoxicity

ÖZ

Amaç: Tiyoasetamid (TAA), karaciğere zarar veren beyaz kristalli bir organosülfür bileşiğidir. Ancak birçok organ üzerine toksik etkiler gösterir. Antioksidan özelikleri ile bilinen nerolidol (NRL) tiyoasetamitin kalp ve böbrek dokularında neden olduğu oksidatif stresi önler ve lipit peroksidasyonunu azaltır. Bu çalışmanın amacı, NRL'nin TAA kaynaklı nefrotoksisite ve kardiyotoksisitesinin ratların üzerindeki koruyucu etkisi araştırmaktır.

Gereç ve Yöntemler: Otuz iki adet Wistar Albino erkek sıçan (3-4 aylık ve ağılıkları 280-300 gr) dört gruba ayrıldı. (a) Kontrol grubu, (b) TAA grubu haftada iki kez 200 mg/kg i.p. olarak uygulanmıştır, (c) NRL grubu, gavaj yoluyla her gün 100 mg/kg dozunda oral yoldan uygulanmıştır. (d) TAA ve NRL grubu, üç hafta süreyle $200 \mathrm{mg} / \mathrm{kg}$ TAA ve $100 \mathrm{mg} / \mathrm{kg}$ NRL uygulanmıştır.

Bulgular: Bu dozların uygulaması sonucunda tiyobarbitürik asit reaktif maddelerin (TBARS) seviyeleri, süperoksit dismutaz (SOD), katalaz (CAT), glutatyon (GSH) ve glutatyon peroksidaz (GPX) seviyeleri tespit edilmiștir. Sonuçlar, TAA'nın kontrol grubuna kıyasla TBARS seviyesinde önemli bir artışa ve kalp ve böbrek dokularında GPx, CAT, SOD ve GSH seviyelerinde önemli bir düşüșe neden olduğu gösterilmiștir. Bu çalıșmanın sonucunda, NRL uygulamasının TBARS düzeylerini önemli ölçüde azaltı̆̆ı ve antioksidan enzimleri artırdığı bulunmuştur.

Sonuç: Bu çalışmanın sonuçları, NRL'nin antioksidan aktivitesinin, TAA'nın kalp ve böbrek dokusunda neden olduğu biyokimyasal ve histolojik hasara karşı koruyabildiğini göstermektedir.

Anahtar kelimeler: Nerolidol, tiyoasetamid, lipid peroksidasyonu, nefrotoksisite, kardiyotoksisite 


\section{INTRODUCTION}

Nowadays, it has increased serious organ damage as a result of acute and chronic exposure to toxic chemicals. 'Thioacetamide (TAA); is a chemical used in industrial areas such as leather, textile, and paper and in laboratories as an organic solvent. ${ }^{2}$ TAA has significant toxic effects on organs such as the liver, kidney, spleen, lung, intestine, stomach, and brain, causing structural and functional modification. ${ }^{3}$ TAA is metabolized in vivo to free radical derivatives, TAA sulfoxide and TAA-S, S-dioxide, resulting in increased lipid peroxidation, resulting in reactive oxygen species (ROS) formation and thus multi-organ damage. ${ }^{1,4}$

Increased free radical development or reduced free radical scavenging is responsible for oxidative stress. Oxidative stress is a major imbalance between free radical development and defense mechanisms against antioxidants. ${ }^{5,6}$ Pro-oxidant agents are primarily constituted by ROS and nitrogenous species. ${ }^{7,8}$

The generation of a large amount of ROS due to TAA can inhibit the antioxidant defense mechanism. ${ }^{4}$ TAA can damage cellular ingredients such as lipids, proteins, and DNA; TAA can impair cellular structure and function. Intracellular antioxidant system compounds [like glutathione (GSH) and other thiols] can be insufficient to proper this damage. The damage of TAA on the heart was evaluated based on the oxidative stress both biochemical and histological. The heart damage is characterized by ROS occurrence, lipid peroxidation, and adverse impacts on the antioxidant-oxidant system. ${ }^{9}$ Some studies have shown that oxidative stress plays an important role in TAA-induced toxicity. However, it has been suggested that various antioxidant treatments show beneficial effects by reducing oxidative stress. ${ }^{10,11}$

Recently, in addition to modern treatment methods, plant-based treatments have become more important.12 The progression of technology and the serious side effects of pharmaceutical agents used in medical treatment have increased the interest in medicinal plants and enabled the investigation of bioactive compounds found in these plants.

Natural components are a present source of antioxidants and many researchers based on discovering new antioxidant compounds from plants. An increasing number of studies have shown that essential oils obtained from medicinal plants exhibit various biological properties. ${ }^{13}$ Antioxidants found in plants are being investigated to treat many disorders such as cardiovascular diseases, cancer, and neurological condition.13,14 Nerolidol (NRL) is found in different plant species, Ferula fukanensis, Baccharis dracunculifolia, Amaranthus retroflexus and Canarium schweinfurthi. ${ }^{15-17} \mathrm{NRL}$, also known as '3,7,11-trimethyl1,6,10-dodecatrien-3-ol' is aliphatic xylene alcohol derived from many plants with antioxidant properties. ${ }^{18}$ The antioxidant, radical scavenging, and anti-inflammatory effects of NRL have been demonstrated in several studies. Nogueira Neto et al. ${ }^{19}$ found that essential oils from Ferula fukanensis containing NRL induced a decrease in nitric oxide production and restricts gene expression NO-induced. In this context, NRL can be suggested utilization as an antioxidant agent.19,20 Although there is currently limited information about the bioactivity of essential oils, it easily crosses the cell membrane and can interact with intracellular proteins. Therefore, many studies have implicated the free radical scavenging properties of essential oils. Studies have shown the antioxidant, radical scavenging, and antiinflammatory effects of NRL. ${ }^{21}$ Additionally, Javed et al. ${ }^{22}$ found that administration of $\mathrm{NRL}(50 \mathrm{mg} / \mathrm{kg}$, i.p.) to rats reversed inflammation and oxidative stress by increasing levels of the antioxidant enzymes superoxide dismutase (SOD), catalase (CAT), GSH and decreasing lipid peroxidation and thiobarbituric acid reactive substances (TBARS) levels. In this context, Nogueira Neto et al. $^{19}$ found that treatment with $\mathrm{NRL}$ (75 mg/kg, i.p.) decreased oxidative stress in the mouse, resulting in increased SOD and CAT activity. Previous studies have suggested that therapeutic potential of NRL to treat and prevent diseases associated with oxidative stress. According to the literature, no previous study investigated the efficacy of NRL on cardiac ameliorates. ${ }^{23,24}$

Therefore, this study investigated the protection of NRL, which is thought to have high antioxidant potential against the cardiotoxic and nephrotoxic effects of TAA. For this purpose, histopathological and biochemical effects of TAA on the heart and kidney were examined and the protective effect of NRL on these parameters was investigated.

\section{MATERIALS AND METHODS}

\section{Animals and treatment}

This study was approved by the Ethics Committee on Animal Research of Pamukkale University (protocol number: 2020/20) and conducted in accordance with the Guidelines for Animal Research from the National Institutes of Health. Pamukkale University Laboratory Animals Reserch Center (Denizli, Turkey) provided the male Wistar Albino rats (weighing 280-300 g). Animals were housed in sterilized polypropylene cages, and fed ad libitum with standard commercial food pellets and water. Animals were randomly divided into 4 groups with eight animals in each group:

1) In the control group, the rats were administered with corn oil alone as vehicle.

2) In the TAA group, the rats were administered with TAA 200 $\mathrm{mg} / \mathrm{kg}$, intraperitoneal (i.p.) twice per week for three weeks,

3) In the NRL group, the rats were administered with NRL 100 $\mathrm{mg} / \mathrm{kg}$ by gavage every other day,

4) In the TAA + NRL group, the rats were administered $200 \mathrm{mg} /$ kg TAA i.p. twice a week and NRL $100 \mathrm{mg} / \mathrm{kg}$ for 21 consecutive days.

After three weeks of treatment, all rats were euthanized under anesthesia. Heart and kidney tissue samples were collected for biochemical analyses and histological examination.

\section{Biochemical assay}

Tissues were homogenized for biochemical parameters examination. TBARS-level tissue homogenates were determined using a spectrophotometric process that is focused 
on the reaction between thiobarbituric acid and $d^{25,26} \mathrm{GSH}$ levels of tissues were determined at $412 \mathrm{~nm}$ according to the Sedlak and Lindsay ${ }^{27}$ method. The results were expressed as $\mathrm{nmol} / \mathrm{mL}$. SOD activity was determined by the method of Sun et al. ${ }^{28}$ using spectrophotometrically. SOD enzyme activity was determined in the inhibition of nitro blue tetrazolium depend on xanthine/ xanthine oxidase enzyme activity $\mathrm{O}^{-2}$. The tissues were measured at $560 \mathrm{~nm}$ in spectrophotometer. ${ }^{28}$ We determined CAT levels of tissues according to the Aebi ${ }^{29}$ method. Glutathione peroxides (GPx) level was determined as spectrophotometrically using method of Paglia and Valentine. ${ }^{30}$ The tissue protein content was calculated by the method of Lowry et al. ${ }^{31}$

\section{Histopathological assay}

For light microscopic evaluation, liver and brain samples were fixed in $10 \%$ formalin. The tissue samples were processed by routine tissue techniques and were embedded in paraffin. Paraffin-embedded specimens were cut into $5 \mathrm{~mm}$ thick sections, mounted on slides, and stained with hematoxylineosin. We examined stained sections under a LeicaDFC280 light microscope by Leica Q Win and Image Analysis System.

We examined heart sections for hemorrhage, necrosis, vascular congestion, vacuolization, mononuclear cell infiltration, oedema and eosinophilic stained and pyknotic nuclei cells.

We examined kidney sections for inflammatory cell infiltration, hemorrhage, glomerular degeneration, vascular congestion, hemorrhage between the tubules, vacuolization of tubular epithelial cells and oedema between the tubules, epithelial atrophy, and cell desquamation in the tubules and casts in tubular lumen. Histopathologic damage score was calculated using these findings. Histopathologic damage score was calculated according to the degree of damage severity to 0 (none), 1 (mild), 2 (moderate), 3 (severe).

\section{Statistical analysis}

ANOVA (post-hoc Tukey test) was performed for comparing biochemical, histopathological, and immunohistochemical scores between the groups. Statistical calculations were carried out using the SPSS 18.0 program package (SPSS Inc., Chicago, IL, USA). Variables were presented as mean \pm standard deviations and $p<0.05$ was the gauge to indicate statistical significance.

Histopathological data analysis was used SPSS 13.0 (SPSS Inc., Chicago, IIl., USA) and MedCalc 11.0 (Belgium) statistical programs. The data are expressed as the arithmetic mean \pm standard error. Kruskal-Wallis and Connover tests were used. Exact $p$ values were given where available, and $p<0.001$ was considered statistically significant.

\section{RESULTS}

\section{Biochemical results}

The antioxidant (SOD, CAT, GPx and GSH) and oxidant (TBARS) levels of the heart tissues are presented in Table 1. In TAA group, the results showed that the SOD, GPx, CAT, GPx and GSH levels were significantly $(p<0.001)$ diminished, whereas the TBARS levels were significantly ( $p<0.001$ ) increased compared with the control group. It was shown that TAA significantly increased the lipid peroxidation in heart tissue. Also, it was determined that there were not any significant changes between the control and NRL groups in terms of SOD, CAT and GSH levels. In TAA + NRL group, the values of TBARS and SOD were similar to control and reversed the effect of TAA on these values. However, the GSH, CAT, GPx levels were changed, but it was not in a statistically significant range. Besides, the TAA + NRL group showed SOD, GPx, CAT and GSH an increase in activities compared with the TAA group. Generally, the results showed that NRL significantly reduced lipid peroxidation in heart tissue.

The antioxidant (SOD, CAT, GPx and GSH) and oxidant (TBARS) levels of the kidney tissues are presented in Table 2. In TAA group, the results showed that the SOD, GPx, CAT, GPx and GSH levels were significantly $(p<0.001)$ diminished, whereas the TBARS levels were significantly $(p<0.001)$ increased compared with the control group. It was shown that TAA significantly increased the lipid peroxidation in kidney tissue. Also, it was showed that there were not any significant changes between the control and NRL groups in terms of SOD and CAT levels. In TAA + NRL group, the values of GSH, CAT and GPx were similar to control. Besides, the TAA+ NRL group showed SOD, GPx, CAT and GSH an increase in activities compared with the TAA group. Generally, the results showed that NRL significantly reduced lipid peroxidation in kidney tissue.

\section{Histopathological results}

In control (Figure 1A, Figure 2A) and NRL (Figure 1B, Figure 2B) groups, heart and kidney tissue were observed in normal histological appearance. In control and NRL groups heart tissue showed a normal myofibrillar structure with striations, branched appearances, and continuity with adjacent myofibrils. In control and NRL groups kidney tissue showed a normal

Table 1. The effect of nerolidol on oxidative stress markers of heart tissues in rats. Values are presented as means \pm SD

\begin{tabular}{llllll} 
& $\begin{array}{l}\text { TBARS } \\
\text { (nmol/g tissue) }\end{array}$ & $\begin{array}{l}\text { Reduced GSH } \\
(\mathrm{nmol} / \mathrm{mL} \text { tissue) }\end{array}$ & $\begin{array}{l}\text { CAT } \\
(\mathrm{k} \text { U/mg protein) }\end{array}$ & $\begin{array}{l}\text { SOD } \\
\text { (U/mg protein) }\end{array}$ & $\begin{array}{l}\text { GPx } \\
(\mathrm{U} / \mathrm{mg} \text { protein) }\end{array}$ \\
\hline Control & $11.49 \pm 3.43^{y}$ & $41.82 \pm 6.51^{y, z}$ & $0.302 \pm 0.10^{y, z}$ & $86.68 \pm 7.71^{z}$ & $0.55 \pm 0.09^{y, z}$ \\
\hline TAA & $17.42 \pm 1.64^{x, z}$ & $17.64 \pm 0.93^{x, z}$ & $0.004 \pm 0.0002^{x}$ & $66.98 \pm 9.32^{z}$ & $0.12 \pm 0.02^{x}$ \\
\hline NRL & $3.79 \pm 0.46^{x, y, z}$ & $49.38 \pm 6.78^{x, y, z}$ & $0.013 \pm 0.0002^{x}$ & $87.45 \pm 2.11$ & $0.39 \pm 0.01^{x, z}$ \\
\hline TAA + NRL & $8.44 \pm 0.28^{y}$ & $27.58 \pm 1.04^{x, y, z}$ & $0.009 \pm 0.003^{x}$ & $78.96 \pm 13.18^{x, y}$ & $0.18 \pm 0.06^{x}$ \\
\hline
\end{tabular}

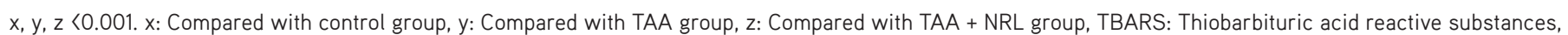
GSH: Glutathione, CAT: Catalase, SOD: Superoxide dismutase, GPx: Glutathione peroxidase, SD: Standard deviation, TAA: Thioacetamide, NRL: Nerolidol 
Table 2. The effect of nerolidol on oxidative stress markers of kidney tissues in rats. Values are presented as means \pm SD

\begin{tabular}{|c|c|c|c|c|c|}
\hline & $\begin{array}{l}\text { TBARS } \\
\text { (nmol/g tissue) }\end{array}$ & $\begin{array}{l}\text { Reduced GSH } \\
\text { (nmol/ml tissue) }\end{array}$ & $\begin{array}{l}\text { CAT } \\
\text { (k U/mg protein) }\end{array}$ & $\begin{array}{l}\text { SOD } \\
\text { (U/mg protein) }\end{array}$ & $\begin{array}{l}\text { GPx } \\
\text { (U/mg protein) }\end{array}$ \\
\hline Control & $4.07 \pm 0.89^{y, z}$ & $52.75 \pm 2.93^{z}$ & $0.013 \pm 0.002$ & $113.13 \pm 9.12^{z}$ & $0.12 \pm 0.03^{y}$ \\
\hline TAA & $9.45 \pm 0.76^{x}$ & $40.78 \pm 4.18^{z, y, z}$ & $0.007 \pm 0.001^{x, y, z}$ & $42.79 \pm 16.16^{x, y}$ & $0.06 \pm 0.04^{x, y, z}$ \\
\hline NRL & $2.96 \pm 0.14^{x, y, z}$ & $63.05 \pm 7.98^{x, y}$ & $0.016 \pm 0.002^{z}$ & $112.74 \pm 29.37^{z}$ & $0.49 \pm 0.02^{x, z}$ \\
\hline $\mathrm{TAA}+\mathrm{NRL}$ & $8.49 \pm 0.36^{x}$ & $59.48 \pm 3.79^{z}$ & $0.013 \pm 0.008^{y}$ & $68.53 \pm 11.54^{x, y}$ & $0.15 \pm 0.03^{y}$ \\
\hline
\end{tabular}

$x, y, z$ <0.001. $x$ : Compared with control group, $y$ : Compared with TAA group, $z$ : Compared with TAA + NRL group, TBARS: Thiobarbituric acid reactive substances, GSH: Glutathione, CAT: Catalase, SOD: Superoxide dismutase, GPx: Glutathione peroxidase, SD: Standard deviation, TAA: Thioacetamide, NRL: Nerolidol

tubular and glomerular structure. Cardiac muscle cells were also normal; their large purple nucleus was located in the center of their pink colored cytoplasm.

In heart tissue of the TAA group, we detected hemorrhage (Figure 3A-C, F), necrosis (Figure 3B), eosinophilic stained and pyknotic nuclei cells (Figure $3 C$ ), oedema and vacuolization (Figure 3D), vascular congestion (Figure 3E), mononuclear cell infiltration (Figure 3F).

In kidney tissue of the TAA group, we detected inflammatory cell infiltration (Figure $4 A, B, D$ ), hemorrhage (Figure 4A, D, E), glomerular degeneration (Figure 4B-D), vascular congestion (Figure 4D), vacuolization of tubular epithelial cells and oedema between the tubules (Figure 4E), epithelial atrophy and cell desquamation in the tubules and casts in tubular lumen (Figure 4F).

Histological changes were more severe in the TAA group than in the group of treatment. However, histopathological

CONTROL

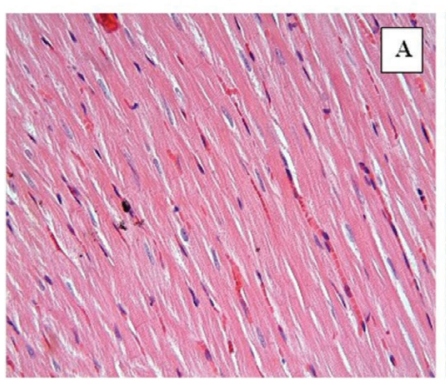

Figure 1. In control (A) and NRL (B) groups; heart tissue showed normal histological appearance. A, B: $\mathrm{H}-\mathrm{E} ; \mathrm{X} 40$

NRL: Nerolidol, H-E: Hematoxylin-eosin
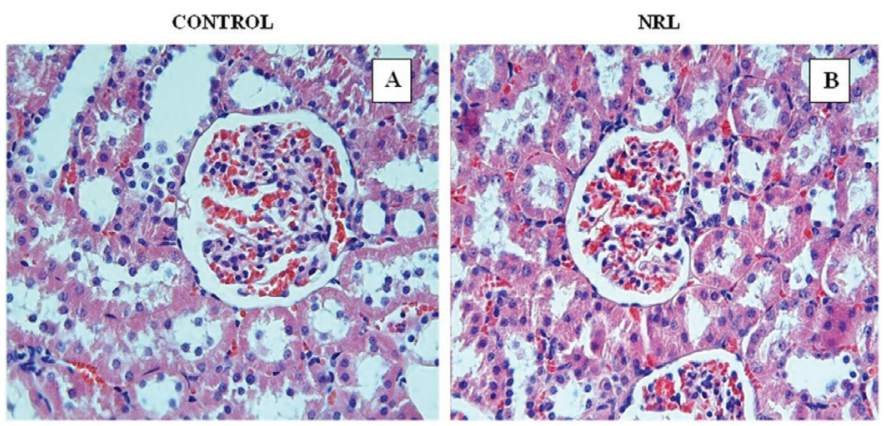

Figure 2. In control (A) and NRL (B) groups; kidney tissue showed normal histological appearance. A, B: H-E; X40

NRL: Nerolidol, H-E: Hematoxylin-eosin damage decreased in the TAA + NRL (Figure 5,6 ) group. NRL administration reduced TAA induced in comparison to compare to that of TAA treated groups for heart and kidney tissues. In addition, microscopic damage score results of all four groups in are demonstrated in Table 3. Accordingly, NRL significantly decreased the histopathological damage score caused by TAA.

\section{DISCUSSION}

The reason for the toxic effect of TAA, which is used as a metal sulfide source, on tissues such as the heart, liver, kidney, and

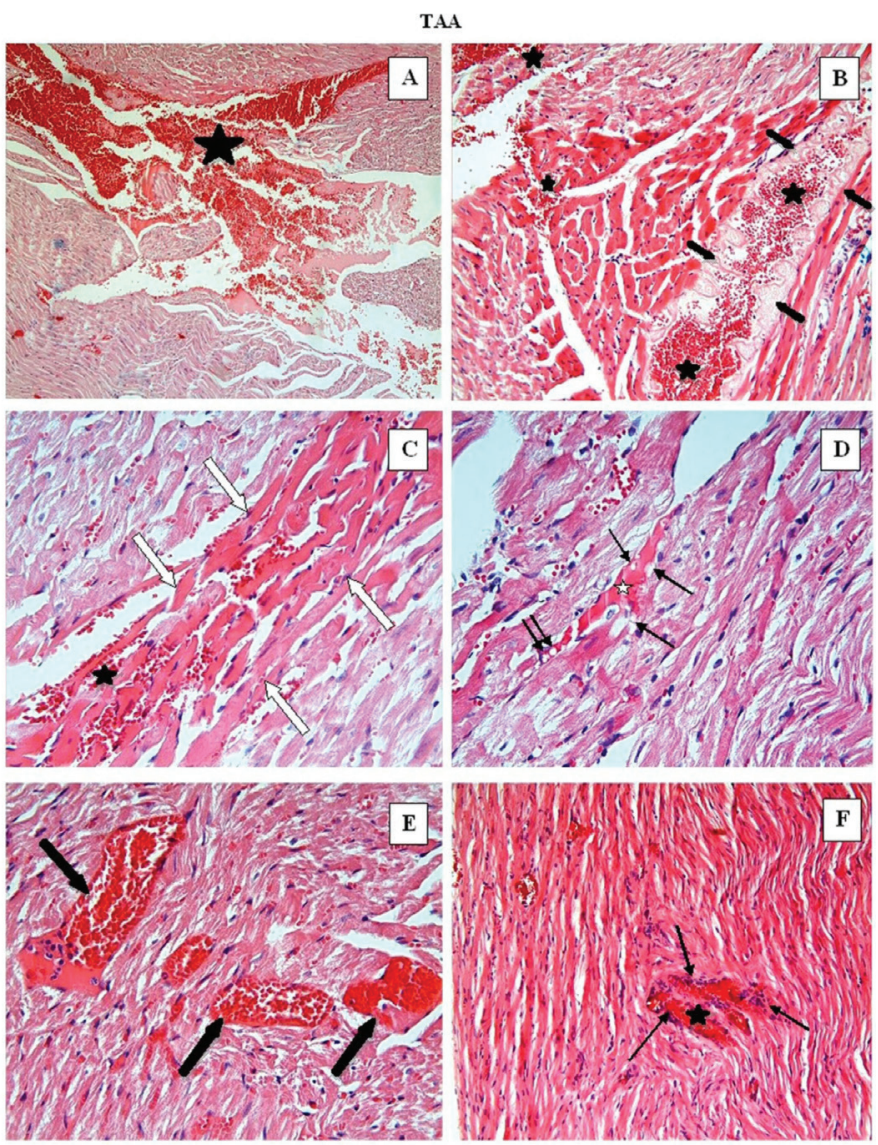

Figure 3. In TAA group: Hemorrhage (black asterisk) (A-C, F), necrosis (thick black arrows) (B), eosinophilic stained and pyknotic nuclei cells (white arrows) (C, F), oedema (white asterisk) and vacuolisation (thin black arrows) (D), vascular congestion (E), mononuclear cell infiltration (thin black arrows) were observed in heart tissue. A: H-E; X10 B, F: H-E; X2O, C-E: H-E; X40

TAA: Thioacetamide, H-E: Hematoxylin-eosin 


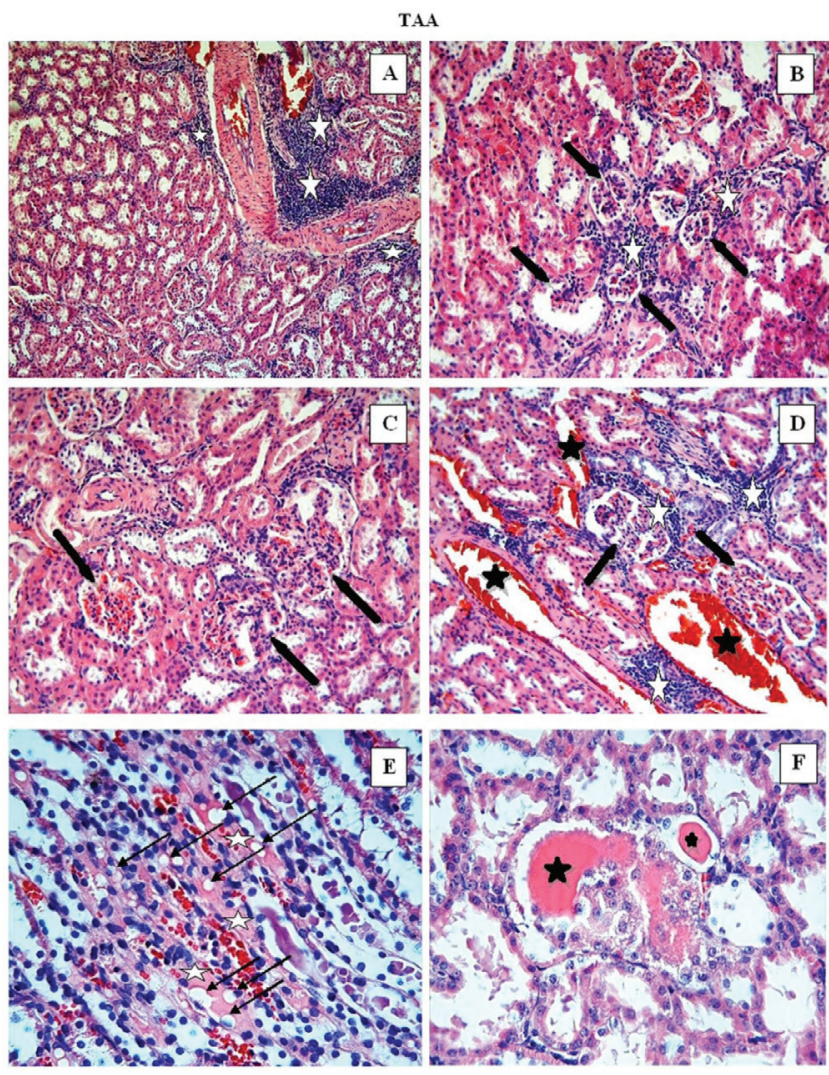

Figure 4. In TAA group; inflammatory cell infiltration (white asterisk) ( $A$, $B, D)$, hemorrhage (A, D, E), glomerular degeneration (black arrows) (B$D$ ), vascular congestion (D), vacuolization of tubular epithelial cells (black arrows) and oedema between the tubules (white asterisk) (E), epithelial atrophy and cell desquamation in the tubules and casts in tubular lumen (F) were observed in kidney. A-C: H-E; X2O, D-F: H-E; X40

TAA: Thioacetamide, H-E: Hematoxylin-eosin
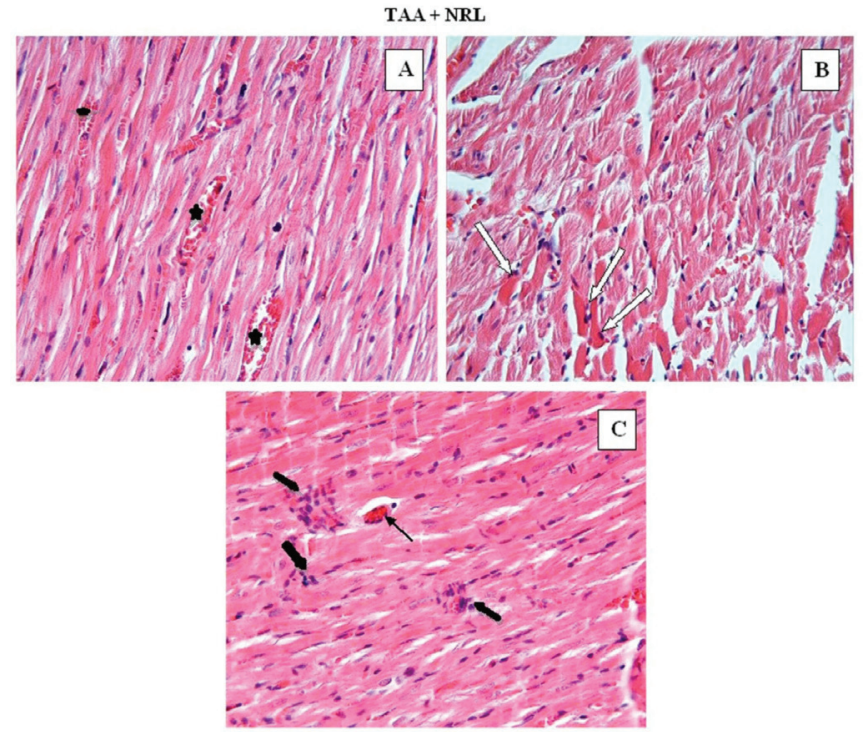

Figure 5. In the TAA + NRL group: Heart tissue findings were decreased compared with the TAA group. Little hemorrhage (black asterisk) (A), a few eosinophilic stained and pyknotic nuclei cells (white arrows) (B), little mononuclear cell infiltration (thick black arrows) and vascular congestion (thin black arrow) (C) were observed in heart tissue. A-C: H-E; X40

TAA: Thioacetamide, NRL: Nerolidol, H-E: Hematoxylin-eosin brain is the induction of oxidative stress. TAA-related toxicity is characterized by increased TBARS levels and increased ROS production. In our study, NRL treatment against TAAinduced heart and kidney toxicity was investigated in terms of antioxidant parameters and histopathological changes. TAA significantly increased TBARS levels in heart and kidney tissue and decreased antioxidant enzymes. Therefore, NRL treatment potentially reduced the side effects of TAA and has been shown to be beneficial against these changes.

Chemicals taken into the organism through environmental and industrial can cause oxidative stress. ${ }^{19}$ Compounds of natural origin can help reverse these effects. Natural antioxidant agents are thought to help prevent imbalances in the antioxidant system that develops because of exposure to toxic substances. Bioflavonoids are naturally obtained and have antioxidant, anti-inflammatory, and antiapoptotic properties. Notably, they

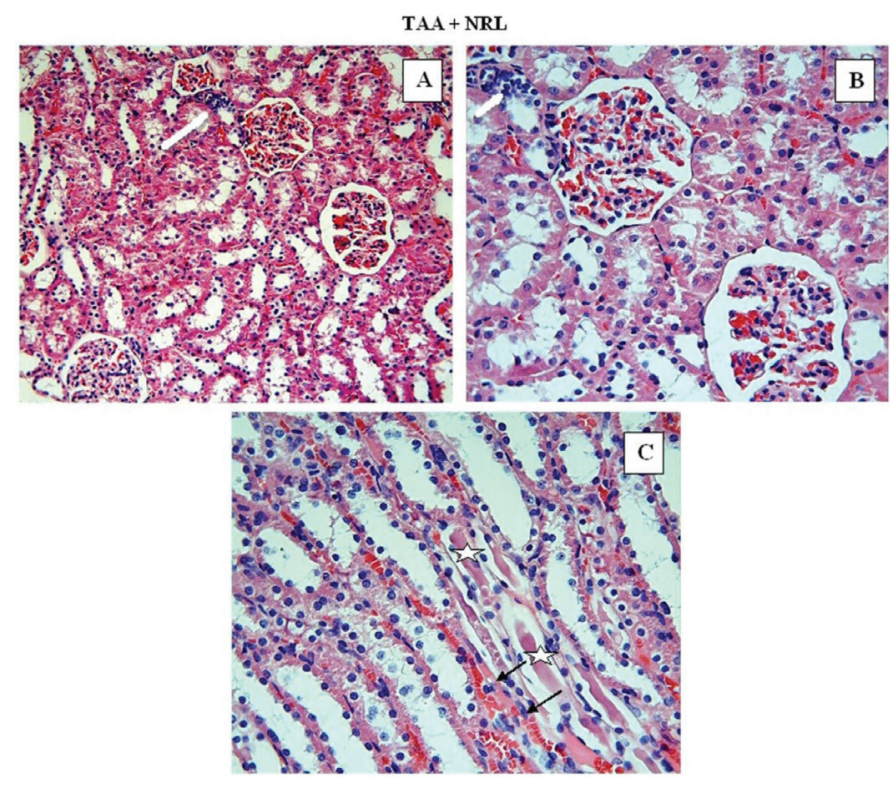

Figure 6. In the TAA + NRL group; kidney tissue findings decreased compared to the TAA group. We observed little inflammatory cell infiltration (white arrows) (A, B), casts in tubular lumen (white asterisk) (B) and a few vacuolization of tubular epithelial cells (B). A, B: H-E; X2O, C: H-E; X40

TAA: Thioacetamide, NRL: Nerolidol, H-E: Hematoxylin-eosin

Table 3. Comparison of the effect of NRL on histopathological damage caused by TAA in heart and kidney tissues (arithmetic mean \pm SE)

\begin{tabular}{lll} 
GROUPS & $\begin{array}{l}\text { Histopathologic } \\
\text { score of heart }\end{array}$ & $\begin{array}{l}\text { Histopathologic } \\
\text { score of kidney }\end{array}$ \\
\hline Control & $0.62 \pm 0.10$ & $0.83 \pm 0.08$ \\
\hline TAA & $2.40 \pm 0.09^{\mathrm{a}}$ & $2.10 \pm 0.14^{\mathrm{a}}$ \\
\hline TAA + NRL & $1.30 \pm 0.07^{\mathrm{b}}$ & $1.45 \pm 0.07^{\mathrm{b}}$ \\
\hline NRL & $0.87 \pm 0.10$ & $0.95 \pm 0.13$ \\
\hline
\end{tabular}

a: There is difference ( $p \leq 0.0001)$ between TAA and the other groups. b: There is difference $(p \leq 0.0001)$ between the TAA + NRL group and the other groups. The mean differences the values bearing different superscript letters within the same column are statistically significant $(p \leq 0,0001)$. TAA: Thioacetamide, NRL: Nerolidol, SE: Standard error 
prevent multiple organ damage caused by oxidative stress and ROS. NRL shows antioxidant activity by eliminating free radicals and ROS. ${ }^{32,33} \mathrm{NRL}$ can prevent lipid peroxidation by lowering TBARS levels. It also prevents the generation of hydroxyl radicals and reduces nitric oxide production. Thus, NRL has radical scavenging activity and is a good antioxidant against oxidative stress. ${ }^{19}$ In previous studies have shown that NRL exhibits strong antioxidant activity at the administration of 25,50 , and $75 \mathrm{mg} / \mathrm{kg}$, causes a considerable reduction in nitric oxide levels and significantly increases SOD and CAT levels. ${ }^{34}$ In this context, it protects cells from impairment due to oxidative damage by enhanced the generation of antioxidant enzymes.

\section{Changes in oxidative stress parameters}

The current different studies demonstrate that the most serious toxic effect of TAA was observed in the liver. TAA can act as an electrophilic agent and S-oxide groups formed by its metabolism attack biomolecules. ${ }^{34}$ Active metabolites due to TAA metabolism bind to cell lipids and proteins by oxidative stress, total antioxidant levels, and binding them to cell lipids and proteins. Increased MDA levels indicate this toxicity. In previous studies, it was determined that increased TBARS in environmental chemical agents rats result from enhanced membrane lipid peroxidation by free radicals and the failure of antioxidant defense mechanisms that prevent formation of excessive free radicals. ${ }^{35,36}$ In the same way, we found that TAA induced oxidative damage, increased TBARS levels, and decreased GSH levels and activities of antioxidant enzymes, including SOD and CAT, in the heart and kidney.

In this study, TAA induced nephrotoxicity by way of enhanced lipid peroxidation, decreased antioxidant enzyme system, and enhanced histopathological damage. Kidneys are highly vulnerable to damage from free radicals and oxidative stress from unsaturated fatty acids. ${ }^{37}$ Free radicals from TAA lead to severe kidney damage. Inflammation, oxidative damage, and apoptosis mechanisms are the most important factors causing renal function impairment. ${ }^{38}$ TAA exposure adversely affects the defense system, which prevents the accumulation of ROS. In another study on cardiac toxicity from 2,3,7,8-tetrachlorodibenzo-p-dioxin (TCDD), cardiac tissue had increased levels of TBARS. The parameters of the antioxidant enzyme activities decrease in the heart tissue due to xenobiotic exposure. ${ }^{39}$ Another study demonstrated that administration of environmental chemical agents to rats leaded to oxidative stress and was associated with significantly lower antioxidant activities of GSH, CAT and SOD. ${ }^{40}$ Thus, this literature confirms our results. In this study, TAA toxicity decreased the activity of GSH, SOD, CAT, and GPx in the kidney and heart tissue. No studies on heart damage caused by TAA exposure have been seen in the literature studies and we think that our study will be the first in this area.

The study demonstrated that TAA induced oxidative stress, which was approved by the decreases of serum SOD and GSH levels. ${ }^{8}$ These results obviously showed that TAA induced oxidative stress in experimental rats. ${ }^{41,42}$ Oxidative stress plays a primary role in the pathogenesis of multiorgan toxicity.
ROS are one of the main causes leading to the progression of pathophysiological changes of the organ injury.

ROS formation occurs in an equilibrium created. However, when external or internal xenobiotics, oxidative stress forms disrupted balance in the heart tissue. ${ }^{43}$ In vivo animal studies show that the resulting ROS lead to heart tissue damage. ${ }^{44,45}$ Celik et al. ${ }^{46}$ were shown that testicular damage induced by TAA is reversed with the antioxidant capacity of NRL. Our study provides a novel perspective on the ameliorating effect of NRL of TAA-induced toxicity in rats.

\section{Histopathological changes}

In different studies, histopathological effects from TAA indicate that the kidney cortex is more affected than the medulla. In the images of the light microscope, significant histopathological changes were observed as a result of glomerular blockage, focal mesangial cell proliferation, increased accumulation of collagen in the renal medulla and fibrin. ${ }^{46}$ Thus, renal cell damage can occur as a decrease in tubules and glomerular filtration rate. ${ }^{47}$

Histopathologically, the toxic effects of TAA on the organs of experimental animals were investigated by several studies. These studies showed that the light microscopic examinations of renal and liver tissue revealed severe histopathological changes. ${ }^{48,49}$ In the study by Ciftci et al. ${ }^{49}$ TAA's tissue toxicity was examined and as part of our study, toxic effects on the kidney and heart tissue were observed. Other studies have shown that nephrons of kidneys are negatively affected by nephrotoxic, xenobiotic, and heavy metal exposure. ${ }^{50}$ One of these adverse effects, a decrease in the functional mass of the kidneys can be shown, leading to a faster cell deaths. In this context, kidney tissue is very vulnerable to such situations. In vivo studies are suggested that exposure to nephrotoxicants has caused considerable cellular damage..$^{51}$ In the study of Barker and Smuckler ${ }^{51}$ were determined renal tubular damage of kidneys TAA-induced as morphologically. The tubular damage is reversed with the Vitex negundo extract used in the study. According to the results of the study, it has been shown that basil leaf extract will be useful as a natural product in the treatment of TAA-induced nephrotoxicity. ${ }^{42}$ The histopathological results of our study were found to be compatible with the literature.

In our previous studies, it was determined that TCDD exposure caused histopathological changes in heart tissue including severe necrosis and bleeding. ${ }^{38}$ In our study, TAA causes histopathological changes in the heart tissue, such as necrosis and bleeding compared with the control group. In another study, TAA was shown to cause histopathological damage to the reproductive system. ${ }^{46}$ We detected histopathological changes decreased significantly with NRL treatment. In this study results are the first to determine that NRL therapy reverts the histopathological damage of TAA on the heart tissue. In our study, it has been shown that NRL treatment can make a significant contribution to the literature as it reduces oxidative damage to the heart tissue and prevents histopathological damage. 


\section{CONCLUSION}

This study shows that NRL can inhibit TAA-induced oxidative damage of the heart and kidneys. As a result, the administration of TAA led to a significant increase in TBARS levels and a significant decrease in antioxidant system (SOD, CAT, GPx and GSH) activities, causing histological damage to the heart and kidney tissue. Therefore, we found that the antioxidant activity of NRL reduces oxidative stress and histopathology in kidney and heart caused by TAA.

Conflict of interest: No conflict of interest was declared by the authors. The authors are solely responsible for the content and writing of this paper.

\section{REFERENCES}

1. Allen JH. The wicked problem of chemicals policy: opportunities for innovation. J Environ Stud Sci. 2012;3:101-108.

2. Caballero ME, Berlanga J, Ramirez D, Lopez-Saura P, Gozalez R, Floyd DN, Marchbank T, Playford RJ. Epidermal growth factor reduces multiorgan failure induced by thioacetamide. Gut. 2001;48:34-40.

3. Pallottini V, Martini C, Bassi AM, Romano P, Nanni G, Trentalance A. Rat HMGCoA reductase activation in thioacetamide-induced liver injury is related to an increased reactive oxygen species content. J Hepatol. 2006;44:368-374.

4. Fabregat I. Dysregulation of apoptosis in hepatocellular carcinoma cells. World J Gastroenterol. 2009;15:513-520.

5. Serafini M, Del Rio D. Understanding the association between dietary antioxidants, redox status and disease: is the total antioxidant capacity the right tool? Redox Rep. 2004;9:145-152.

6. Pisoschi AM, Pop A. The role of antioxidants in the chemistry of oxidative stress: a review. Eur J Med Chem. 2015;97:55-74.

7. Halliwell B, Gutteridge JM. Free radicals in biology and medicine. Oxford University Press, USA. 2015.

8. Winyard PG, Moody CJ, Jacob C. Oxidative activation of antioxidant defence. Trends Biochem Sci. 2005;30:453-461.

9. Lotková H, Cervinková Z, Kucera O, Rousar T, Kriváková P. S-adenosylmethionine exerts a protective effect against thioacetamideinduced injury in primary cultures of rat hepatocytes. Altern Lab Anim. 2007;35:363-371.

10. Osman A, El-Hadary A, Korish AA, AlNafea HM, Alhakbany MA, Awad AA, Abdel-Hamid M. Angiotensin-I converting enzyme inhibition and antioxidant activity of papain-hydrolyzed camel whey protein and its hepato-renal protective effects in thioacetamide-induced toxicity. Foods. 2021;10:468.

11. Saad HM, Oda SS, Sedeek EK. Protective effect of Lactéo ${ }^{\circledR}$ forte against thioacetamide-induced hepatic injury in male albino rats. Alex J Vet Sci. 2020;67:92-98.

12. Bakkali F, Averbeck S, Averbeck D, Idaomar M. Biological effects of essential oils--a review. Food Chem Toxicol. 2008;46:446-475.

13. Asaikumar L, Vennila L, Akila P, Sivasangari S, Kanimozhi K, Premalatha $V$, Sindhu G. Preventive effect of nerolidol on isoproterenol induced myocardial damage in Wistar rats: evidences from biochemical and histopathological studies. Drug Dev Res. 2019;80:814-823.

14. Abdelbaset MS, Abdel-Aziz M, Abuo-Rahma GEA, Abdelrahman MH, Ramadan M, Youssif BGM. Novel quinoline derivatives carrying nitrones/oximes nitric oxide donors: design, synthesis, antiproliferative and caspase-3 activation activities. Arch Pharm (Weinheim). 2019;352:e1800270.

15. Pinheiro BG, Silva ASB, Souza GEP, Figueiredo JG, Cunha FQ, Lahlou S, da Silva JKR, Maia LGS, Sousa PJC. Chemical composition, antinociceptive and anti-inflammatory effects in rodents of the essential oil of Peperomia serpens (Sw.) Loud. J Ethnopharmacol. 2011;138:479486.

16. Parreira NA, Magalhães LG, Morais DR, Caixeta SC, de Sousa JP, Bastos JK, Cunha WR, Silva ML, Nanayakkara NP, Rodrigues V, da Silva Filho AA. Antiprotozoal, schistosomicidal, and antimicrobial activities of the essential oil from the leaves of Baccharis dracunculifolia. Chem Biodivers. 2010;7:993-1001.

17. Klopell FC, Lemos M, Sousa JP, Comunello E, Maistro EL, Bastos JK, de Andrade SF. Nerolidol, an antiulcer constituent from the essential oil of Baccharis dracunculifolia DC (Asteraceae). Z Naturforsch C J Biosci. 2007;62:537-542.

18. Chan WK, Tan LT, Chan KG, Lee LH, Goh BH. Nerolidol: A sesquiterpene alcohol with multi-faceted pharmacological and biological activities. Molecules. 2016;21:529.

19. Nogueira Neto JD, de Almeida AA, da Silva Oliveira J, Dos Santos PS, de Sousa DP, de Freitas RM. Antioxidant effects of nerolidol in mice hippocampus after open field test. Neurochem Res. 2013;38:1861-1870.

20. Bagamboula CF, Uyttendaele M, Debevere J. Inhibitory effect of thyme and basil essential oils, carvacrol, thymol, estragol, linalool and p-cymene towards Shigella sonnei and S. flexneri. Food Microbiol. 2004:21:33-42.

21. Péres VF, Moura DJ, Sperotto AR, Damasceno FC, Caramão EB, Zini CA, Saffi J. Chemical composition and cytotoxic, mutagenic and genotoxic activities of the essential oil from Piper gaudichaudianum Kunth leaves. Food Chem Toxicol. 2009;47:2389-2395.

22. Javed H, Azimullah S, Khair SBA, Ojha S, Haque ME. Neuroprotective effect of nerolidol against neuroinflammation and oxidative stress induced by rotenone. BMC Neurosci. 2016;17:1-12.

23. Motai T, Kitanaka S. Sesquiterpenoids from Ferula fukanensis and their inhibitory effects on nitric oxide production. Journal of Natural Medicines. 2006;60:54-57.

24. Lapczynski A, Bhatia SP, Letizia CS, Api AM. Fragrance material review on nerolidol (isomer unspecified). Food Chem Toxicol. 2008;(Suppl 11):S247-S250.

25. Yagi K. Simple assay for the level of total lipid peroxides in serum or plasma. Methods Mol Biol. 1988;108:101-106.

26. Montjean D, Ménézo Y, Benkhalifa M, Cohen M, Belloc S, Cohen-Bacrie $\mathrm{P}$, de Mouzon J. Malonaldehyde formation and DNA fragmentation: two independent sperm decays linked to reactive oxygen species. Zygote. 2010;18:265-268.

27. Sedlak J, Lindsay RH. Estimation of total, protein-bound, and nonprotein sulfhydryl groups in tissue with Ellman's reagent. Anal Biochem. 1968;25:192-205.

28. Sun Y, Oberley LW, Li Y. A simple method for clinical assay of superoxide dismutase. Clin Chem. 1988;34:497-500. 
29. Aebi H. Catalase In: Methods of Enzymatic Analysis. Bergmeyer HU (ed). 1974;673-677.

30. Paglia DE, Valentine $W N$. Studies on the quantitative and qualitative characterization of erythrocyte glutathione peroxidase. J Lab Clin Med. 1967;70:158-169.

31. Lowry OH, Rosebrough NJ, Farr AL, Randall RI. Protein measurement with Folin phenol reagent. J Biol Chem. 1951;193:265-275.

32. Vinholes J, Gonçalves P, Martel F, Coimbra MA, Rocha SM. Assessment of the antioxidant and antiproliferative effects of sesquiterpenic compounds in in vitro Caco-2 cell models. Food Chem. 2014;156:204211.

33. Wang CY, Wang SY, Chen C. Increasing antioxidant activity and reducing decay of blueberries by essential oils. J Agric Food Chem. 2008;56:3587-3592.

34. Koen YM, Sarma D, Hajovsky H, Galeva NA, Williams TD, Staudinger $\mathrm{JL}$, Hanzlik RP. Protein targets of thioacetamide metabolites in rat hepatocytes. Chem Res Toxicol. 2013;26:564-574.

35. Liu J, Tan H, Sun Y, Zhou S, Cao J, Wang F. The preventive effects of heparin-superoxide dismutase on carbon tetrachloride-induced acute liver failure and hepatic fibrosis in mice. Mol Cell Biochem. 2009;327:219-228.

36. Kim HY, Kim JK, Choi JH, Jung JY, Oh WY, Kim DC, Lee HS, Kim YS, Kang SS, Lee SH, Lee SM. Hepatoprotective effect of pinoresinol on carbon tetrachloride-induced hepatic damage in mice. J Pharmacol Sci. 2010;112:105-112.

37. Ozbek E. Induction of oxidative stress in kidney. Int J Nephrol. 2012;1-9.

38. Silva FG. Chemical-induced nephropathy: a review of the renal tubulointerstitial lesions in humans. Toxicol Pathol. 2004(Suppl 2):7184.

39. Ciftci O, Disli OM, Timurkaan N. Protective effects of protocatechuic acid on TCDD-induced oxidative and histopathological damage in the heart tissue of rats. Toxicol Ind Health. 2013;29:806-811.

40. Çetin A, Çiftçi O, Otlu A. Protective effect of hesperidin on oxidative and histological liver damage following carbon tetrachloride administration in Wistar rats. Arch Med Sci. 2016;12:486-493.
41. El-Desouky MA, Mahmoud MH, Riad BY, Taha YM. Nephroprotective effect of green tea, rosmarinic acid and rosemary on $\mathrm{N}$-diethylnitrosamine initiated and ferric nitrilotriacetate promoted acute renal toxicity in Wistar rats. Interdiscip Toxicol. 2019;12:98-110.

42. Alomar MY. Physiological and histopathological study on the influence of Ocimum basilicum leaves extract on thioacetamide-induced nephrotoxicity in male rats. Saudi J Biol Sci. 2020;27:1843-1849.

43. Braunwald E. Coronary blood flow and myocardial ischemia. Heart disease: a textbook of cardiovascular medicine. W.B. Saunders Company. Philadelphia, Pennsylvania, USA. 2001;1161-1183.

44. Sabri A, Hughie HH, Lucchesi PA. Regulation of hypertrophic and apoptotic signaling pathways by reactive oxygen species in cardiac myocytes. Antioxid Redox Signal. 2003;5:731-740.

45. Sawyer DB, Siwik DA, Xiao L, Pimentel DR, Singh K, Colucci WS. Role of oxidative stress in myocardial hypertrophy and failure. J Mol Cell Cardiol. 2002;34:379-388.

46. Celik H, Camtosun A, Ciftci $O$, Cetin A, Aydın M, Gürbüz S. Beneficial effects of nerolidol on thioacetamideinduced damage of the reproductive system in male rats. Biomed Res. 2016;725-730.

47. Mahmoud NH. Protective effect of Panax ginseng against thioacetamide cytotoxicity in liver and kidney of albino rat. J Egypt Soc Toxicol. 2006:34:43-54.

48. Kadir FA, Kassim NM, Abdulla MA, Yehye WA. Effect of oral administration of ethanolic extract of Vitex negundo on thioacetamide-induced nephrotoxicity in rats. BMC Complement Altern Med. 2013;13:294.

49. Ciftci O, Ozdemir I, Vardi N, Beytur A, Oguz F. Ameliorating effects of quercetin and chrysin on 2,3,7,8-tetrachlorodibenzo- $\mathrm{p}$-dioxin-induced nephrotoxicity in rats. Toxicol Ind Health. 2012;28:947-954.

50. Ramos-Frendo B, Pérez-Garcia R, López-Novoa JM, HernandoAvendaño L. Increased severity of the acute renal failure induced by $\mathrm{HgCl} 2$ on rats with reduced renal mass. Biomedicine. 1979;31:167-170.

51. Barker EA, Smuckler EA. Nonhepatic thioacetamide injury. II. The morphologic features of proximal renal tubular injury. Am J Pathol. 1974; 74:575-590. 